\title{
Muodonmuutoksia ilman kotilokehtoa
}

\section{Karin Filander (2000). Kehittämistyö murrok- sessa. Sitoutuminen, sopeutuminen ja vas- tarinta julkisella sekto- rilla 1990-luvulla. Acta Universitatis Tampe- rensis 777.}

\section{Tainaron on satumaa,} jossa elämään kuuluvat perusteelliset muodonmuutokset. Niin täydelliset, ettei sellaisen jälkeen edes ystäväänsä voi tunnistaa. Tainaronissa muodonmuutoksia tehdään kaikessa rauhassa, kotilokehdossa. Oikeassa elämässä niitä tehdään työssä keskellä melskettä ja jännitteitä. Karin Filander tutki tätä tapahtumaa. Hän väitteli Tampereen yliopistossa aikuiskasvatuksen alalla joulukuussa 2000. Väitöskirjan nimi on Kehittämistyö murroksessa. Arvioin tutkimusta käytännöstä käsin, kehittämistyön paineissa toimineena koulutusalan edustajana.

\section{Filander tutki julkisen} sektorin kehittäjiä Suomessa 90-luvun ajan. Hän määritteli kehittämistyön tekijöiden kulttuuristen puhetapojen ja kirjoitusten väliseksi neuvottelun ja kamppailun prosessiksi. Tästä näkökulmasta hän lähti tutkimaan markkinaorientoituneen kehittämispuheen aikaa, jota 90-luvulla elettiin. Julkisen sektorin toimintakäytännöt leimattiin menneisyyden ja taantumuksen työtyypeiksi ja työorientaatioksi, mitkä piti korvata yksityiseltä sektorilta johde- tuilla tuloksellisuutta, tehokkuutta ja yrittäjyyttä painottavilla markkinasuuntautuneilla puhetavoilla. Tutkija analysoi tätä kulttuurista muutosprosessia, jonka aikana sosiaalista määriteltiin Suomessa uudelleen. Hän yhdisti keskustelun kehittämistyöstä jälkimodernin ja refleksiivisen yhteiskunnan keskusteluihin, joita hän tarkasteli aikuiskasvatuksen näkökulmasta. Keskeisiä painopisteitä olivat taloudessa ja työelämässä tapahtuvat muutokset ja keskustelu moninaistuvista identiteeteistä. Häntä kiinnosti sosiaalisen ja yksilöllisen leikkauskohta, merkityksenannon sosiaalisuus ja aikuiskouluttajien oma diskursseissa ilmenevä vallankäyttö.

\section{Tutkitut olivat julkisen} sektorin kehittämistyöhön osallistuneita virkamiehiä, ammattilaisia ja kehittäjiä, jotka elivät ja tekivät työtä keskellä 90-luvun nopeita muutoksia. Yhteensä henkilöitä oli 26, joista naisia 19 . Tutkimus käynnistyi koulutusohjelman kautta vuonna 1991 ja henkilöitä haastateltiin uudelleen vuonna 1997. Henkilöt toimivat eri tasoilla ja erilaisissa tehtävissä, myös koulutustaustat erosivat toisistảan. Yhteistä kaikille oli, että heidän oli työssään pakko suhteuttaa itseään markkinakäänteeseen.

\section{Tutkija etsi vastausta}

kysymykseen, miten julkisen sektorin muutosta tehdään. Miten vastarintaa tehdään ja miten jatkuvuutta ylläpide- tään? Tutkija tunnisti erilaisia suhteutuksia 90-luvun markkinamuutokseen; häntä kiinnosti selitysten ja perustelujen moninaisuus sellaisenaan. Jotkut tutkituista sitoutuivat heti muutoksen edistämiseen, jotkut omaksui vastarinnan strategioita ja viivyttivät markkinakäännettä. Metodisesti tutkija pyrki rakentamaan uudenlaista lähestymistapaa muutostutkimukseen, joka oli yleensä sivuuttanut tapahtumien negatiiviset seuraukset ja häviäjät. Ottamalla välimatkaa normatiiviseen hän pyrki lähemmäksi todellisuuden moninaisuutta. Hän rakensi ihannetarinoita vain peileiksi, joihin katsomalla poikkeamat tulevat näkyville.

\section{Tutkimus osoitti ja}

muutenkin on hyvin näkyvissä, että muutosta tehdään varsin mustavalkoisen puheen avulla. Kaikki vanha on ikään kuin huonoa ja vain markkinaorientunut toiminta edustaa hyvää tulevaisuuden mallia. Tällaista kehittäjäpuhetta harrasti suurin osa tutkituista. Loppuhaastatteluun mennessä kaikki olivat oppineet käyttämään sitä, myös vähemmistö, joka alussa määritteli itsensä ammattilaispuheen kautta. Tutkija osoittaa, miten kehittäjät siirtyivät prosessin aikana innostuneesta kauniin puheen kehittämiskertomuksista kovaan puheeseen, jossa markkinakäänteen mukaiset uudet mallit, taloudelliset arvot ja realiteetit karsivat puheesta pehmeitä elementtejä. 


\section{Aiheenvalinta ansaitsee}

kiitosta, tutkija uskaltaa rohkeasti tarttua tärkeisiin kysymyksiin. Kerrankin tutkitaan kysymyksiä, jotka kiinnostavat kehittäjää/ suunnittelijaa/ kouluttajaa. Tutkimus on selkeästi kirjoitettu ja puhuttelee lukijaa, kuten Matti Kortteisen Kunnian kenttä aikanaan. Filanderin tutkimusaineisto antaa lukijalle peilejä tarkastella itseään. Tähän tutkija on pyrkinytkin. Hän toivoo lukijan tunnistavan, että "Tuo on minun tarinani - en ole yksin" (s.83). Tutkimuksen alkuperäinen tarkoitus on auttaa paikantamaan identiteettiään (s.127). Ensimmäisellä lukemisella todella samaistuin joihinkin ajatuskulkuihin ja löysin itseni aineistosta. Olen elänyt samaa murrosta ja koulinut itseni puhumaan markkinapuhetta, saanut itseni uskomaan tulosjohtamiseen ja laatuajatteluun. Tutkimus herättää myös pohtimaan, mihin suuntaan on menossa ja miksi - valtavirran mukana on kovin helppo kulkea.

\section{Muistan tutkijaryhmän}

90-luvun alkupuolella kuvanneen työntekijöiden erilaisia tapoja hahmottaa työtään, nyt tuloksissa abstrahoidutaan enemmän. Tutkija on kiinnostunut vain muutoksen puolesta tai sitä vastaan ulottuvuudesta ja sen eri ilmenemismuodoista. Toisella lukemisella alkaa tuntua, ettei mistään saa kiinni, mitä oikein sanotaan. Jäädäänkö tässä kuitenkin kuvailuun ja yksilötasolle: kun joku sanoo muuttuneensa niin se uskotaan sellaisenaan? Onko tämä uudelleen Kunnian kentän sanoma: keinolla millä tahansa haluan säilyttää ihmisarvoni työelämässä?
Tutkimus pääsee lähelle

käytäntöä. Tutkija on uskaltautunut ja pystynyt dialogiin tutkittavien kanssa. Uskallus aktiiviseen haastatteluun ja aidon vuorovaikutuksen hakemiseen, kohtaamiseen ansaitsee kiitosta. Kuten Antti Eskola sanoi työpäiväkirjassaan 1993 'Tieteen totuus' on usein tosikkomaista, tyhmähköä; 'kansan totuus' ovelampaa ja moniselitteisempää. Tässä valotetaan myös ovelampia totuuksia, joita kehittäjät rakentelevat ollakseen uskottavia itselleen ja/tai ympäristölleen. Saadaan esille vastarinnan muotoja: huumori, suora hyökkäys, vetäytyminen, neutraalisuus. Myös mukaan meneminen voi olla hyvä tapa vastustaa. Avoin markkinapuheen vastarinta ei ole viisasta, mutta ihminen on kekseliäs.

\section{Tutkimus osoitti, miten}

naiskehittäjät rakensivat yksilölliseen sankaruuteen perustuvaa kehittäjän valtaistumispuhetta. He erottuivat minä puheen avulla alistavista ja sukupuolistuneista odotuksista, mitä miesten ei tarvinnut tehdä. Tutkija tulkitsi, että naiskehittäjien oli tehtävä enemmän työtä voidakseen tulla hyväksytyksi autonomisena ja näkyvänä toimijoina kehittämisen pelikentillä. Naisilla oli myös enemmän luopumisen kokemuksia vai onko kyse heidän halukkuudesta kertoa avoimemmin? Miehiä oli vähemmän, eivätkä he suinkaan kaikki ylenneet johtajiksi. Yllättävää lukijalle olivat naisten yksilökeskeisyys ja omavaltaisilta tuntuvat toimintatavat. Jotkut naiset tuntuivat toimivan täysin työyhteisöstä piittaamatta tai manipuloivat muita, asettuivat kaikkien yläpuolelle. Miksi naiset eivät osanneet rakentaa ja käyttää verkostoja - eikö se pitäisi olla naisten vahvaa aluetta? Onko hyvä yhteistyö tosiaan vallitsevaa maskuliinista käytäntöä? Vai elämmekö naiskehittäjien vallanoton alkuvaiheita? Luulin tasaarvoisuuden olevan Suomessa jo pitemmällä.

\section{Tutkimuksen}

tarkoituksena oli tunnistaa, miten diskursiivinen valta toimii kehittämis- ja muutostilanteissa. Miten kehittäjät, muutoksen ammattilaiset ja aikuiskasvattajat käyttävät valtaa nimetessään ja määritellessään muutosta, jonka keskellä elävät. Miten tehdään muutosta ja ylläpidetään jatkuvuutta? Hyviä ja osuvia kuvauksia ainakin saatiin. Väitöskirjan aineisto tuntuu tutulta käytännöstä käsin: tuollaista elämä on. Samalla herää kuitenkin kysymys kehittämistoiminnan ja puheen suhteista. Miten voitaisiin tutkia kehittämistyötä eikä vain siitä käytyä keskustelua? Vallitseva tapa puhua on kuitenkin vain tapa puhua. Tutkija kokeili puheiden yhteyksiä työtehtäviin tai niiden tasoon, mutta luopui yrityksestä. Olisiko se sitten toisen tutkimuksen aihe. Kehittäjänä tarvitsisi työvälineitä muutoskulujen laadun arviointiin, todellisen kehityksen tunnistamiseen. Hyvä kuvaus tapahtumista ei siellä riitä.

Heli Nurmi 